\title{
MALE-MALE AMPLEXUS BETWEEN TWO AMPHIBIAN FAMILIES
}

\author{
Zdeněk Mačát ${ }^{\mathrm{a}^{*}}$, Daniel Jablonski ${ }^{\mathrm{b}}$ and Antonín Reiter
}

aPodyjí National Park Administration, Na Vyhlídce 5, Znojmo, Czech Republic

${ }^{b}$ Department of Zoology, Comenius University in Bratislava, Ilkovičova 6, Mlynská dolina, Bratislava, Slovakia

'South Moravian Museum in Znojmo, Přemyslovců 129/8, Znojmo, Czech Republic

*Corresponding author. E-mail: zdenek.macat@gmail.com

\author{
Article history \\ 17 December 2020; accepted \\ 11 February 2021

\section{Keywords:} \\ breeding ecology; Anura; \\ Bombinatoridae; Hylidae; \\ rare observation
}

\begin{abstract}
The amplexus between two different anuran males is observed very rarely. Therefore, here we provide the first documented observation of a long-lasting male-male amplexus between Bombina bombina (Bombinatoridae) and Hyla arborea (Hylidae) together with an overview of the data published in literature. The observed mating pattern is reported from Southern Moravia, the Czech Republic. The possible reasons for its occurrence during the mass breeding season are discussed.
\end{abstract}

The breeding ecology of anurans is characterized by a wide variety of interactions between males and females (Carvajal-Castro et al. 2020). During the breeding season, frogs generally use acoustic and chemical signals, and/ or visual communication to recognize their conspecifics (Wells 2007; Belanger and Corkum 2009). Most European frogs belong to mass breeding species, which are characterized by a mass clustering of males and females in a breeding site during springtime (Speybroeck et al. 2016). The overlap in breeding phenology between different taxa is very common. During this overlap, different species with similar habitat preferences are present in the same localities and interact with each other. The breeding system of most European frogs is characterized by an active search for reproductive partners during the breeding season (Speybroeck et al. 2016). The overall reproduction success depends on the density of individuals or capacities of males to recognize conspecific females (Arak 1983; Marco and Lizana 2002). This may result in the unusual forms of amplexus that have been described in literature (e.g. Mollov et al. 2010; Simović et al. 2014; Mačát and Jablonski 2018; Ayres and Dominguez-Costa 2020). In this paper, we report a case of male-male amplexus between $B$. bombina and $H$. arborea, which is uncommon as compared to other cases of interspecies amplexus reported in literature.

On 21 May 2019 at 9:25 p.m. (local time - CEST), we observed a male B. bombina (Linnaeus, 1761), of the family Bombinatoridae, engaging in inguinal amplexus with a male $H$. arborea (Linnaeus, 1758), Hylidae, (Figure 1). This case of amplexus was observed in Jánský rybník (fishpond) near the village of Šafov, South Moravia, the Czech Republic (4852'11" N, 1545'19" E; $398 \mathrm{~m}$ a.s.1.). Both species were active during the night
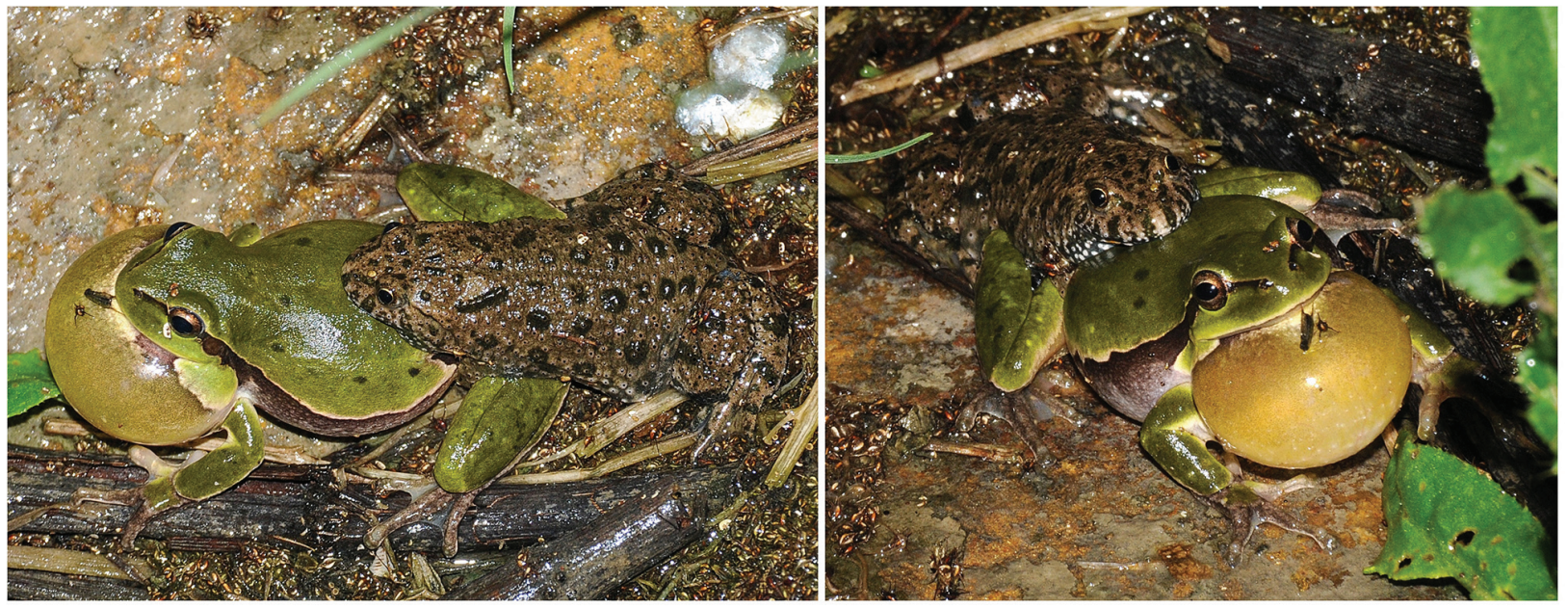

Figure 1. Inguinal amplexus between the male of Bombina bombina (Linnaeus, 1761) and the male of Hyla arborea (Linnaeus, 1758) in Jánský fishpond in the Czech Republic. 
and their choruses were very loud. The pair was found on a wet and damp pond bank, close to water ( $\mathrm{ca} 5 \mathrm{~cm}$ ), and the mating interaction was observed for approximately 8-10 minutes. During the observation, the amplexed $H$. arborea male continued producing mating calls. Only the bottom of the fishpond was filled with water (ca 1.4 ha with 5-10 cm depth) and both individuals were observed in a vast littoral zone.

The fishpond, near which the above-mentioned case of amplexus occurred, had been used for intensive fish production for the last decades. Because of dry periods in the past few years, only a minimal water level was maintained in the pond. Both species are locally common and their populations are known in the locality. Occasionally, Bufo bufo and Pelophylax aff. esculentus are reported here.

In this paper, we provide a brief review of literature on male-male amplexus for the first time. According to the data available, a total of eleven cases of male-male amplexus were reported in the Western Palaearctic area. Occurrence of this phenomenon was reported in four families (Bombinatoridae, Pelobatidae, Bufonidae and Ranidae), which account for $57 \%$ of all the families in the study area. Nine of the recorded amplexus modes were rated as unique. The most often occurring cases of interspecific amplexus were repeatedly recorded only between $P$. ridibundus and B. bufo (3 cases/27.3\%). In addition, one case of the opposite amplexus was recorded between these taxa. The study by Mollov et al. (2010) reported four cases of axillary amplexus (36.4\%), four cases of inguinal amplexus (36.4\%), the position of the other three reported amplexus cases $(27.3 \%)$ being not described. Based on the literary sources available to us, we conclude that our observation of the male-male amplexus between $B$. bombina and $H$. arborea is the first one to be documented. A similar case of the male-male amplexus, in which a $B$. variegata amplexed an $H$. ar- borea male, was photographically documented, without further details, in Romania by Gherghel et al. (2008).

Therefore, here we provide the data from our own observation. The observed species, B. bombina and $H$. arborea, have a similar reproduction period during the breeding season (late spring in Central Europe, i.e., April and May) and they also inhabit similar water habitats (Moravec 2019). Based on our observation, the initiator of the observed case of the amplexus was a B. bombina male. This species is a diurnal frog, with several exceptions (night activity) during the breeding season (Moravec 2019). On the other hand, Hyla arborea is a night-active frog species, distinguished for specific loud call choruses and using axillary amplexus during mating (Moravec 2019). The observed species use different mating strategies and also, both species are evolutionarily distant (Pyron and Wiens 2011). Bombina bombina uses inguinal amplexus and is well known as one of the most toxic toad species in Europe (Speybroeck et al. 2016; Moravec 2019). The toxic glands are uniformly distributed over the body. However, the male body contains more toxic glands than the female one (ca $210 / \mathrm{cm}^{2}$ in males, $v s .70 / \mathrm{cm}^{2}$ in females; Obert and Schneider 1978). Chemical emissions may be important in mating behaviour, especially in small breeding areas. It is known that anuran males can be attracted to substrates containing female-derived chemosignals but not to blank substrates or those containing male scents (Woodley 2014). Thus, it can be assumed that prior to the observed amplexus occurrence, a female $B$. bombina came into close contact with the male $H$. arborea and the odour traces of the female adhered to the moist body of the male $H$. arborea, which subsequently attracted the male $B$. bombina. Toxins are strong chemical signals, even stronger than those that help recognize a potential mating partner (Woodley 2014).

The male-male amplexus between European anuran spe-

Table 1. A summary of published male-male amplexus records in the Western Palaearctic anuran species.

\begin{tabular}{|l|l|l|l|l|}
\hline \multicolumn{1}{|c|}{ Species } & \multicolumn{1}{|c|}{ Amplexus with } & \multicolumn{1}{c|}{ Type } & \multicolumn{1}{c|}{ Locality } & \multicolumn{1}{c|}{ Reference } \\
\hline Bombinatoridae & & & & \\
\hline Bombina variegata & Hyla arborea & inguinal & Romania & Gherghel et al. 2008 \\
\hline Bombina bombina & Hyla arborea & inguinal & Czech Republic & this study \\
\hline Pelobatidae & Bufo bufo & & & \\
\hline Pelobates fuscus & & inguinal & Czech Republic & Mačát and Jablonski 2018 \\
\hline Bufonidae & Pelophylax ridibundus & axillary & Romania & Strugariu and Gherghel 2008 \\
\hline Bufotes viridis & Bufotes viridis & - & Bulgaria & Mollov et al. 2010 \\
\hline Bufotes viridis & Bufo bufo & - & Bulgaria & Mollov et al. 2010 \\
\hline Bufo bufo & Rana temporaria & inguinal & Bulgaria & Mollov et al. 2010 \\
\hline Bufo bufo & & & & \\
\hline Ranidae & Rana temporaria & - & Bulgaria & Mollov et al. 2010 \\
\hline Rana temporaria & Bufo bufo & axillary & Bulgaria & Mollov et al. 2010 \\
\hline Pelophylax ridibundus & Bufo bufo & axillary & Bulgaria & Mollov et al. 2010 \\
\hline Pelophylax ridibundus & & & & \\
\hline
\end{tabular}


cies is uncommonly reported in literature (see Table 1), which could be explained by the following reasons: i) the amplexus of two males of the same species can often be overlooked, assuming that a regular amplexus between a male and a female is being observed; ii) duration of similar observations; it is well-known that males emit release calls, coupled with small amplitude body-side vibration during the contact of two conspecific males, which leads to fast interruption of any male-male amplexus (Schmidt 1972; Toledo et al. 2015). These factors, together with the fieldwork effort could explain the relatively low number of such records in literature, despite the well-known fact that during the breeding season males commonly confuse females with different subjects (Mollov et al. 2010; Zimić et al. 2018).

\section{ACKNOWLEDGMENT}

We are grateful to Lenka Libusová for her help in the field, Mariel Sporn Tavakoli for language correction and two anonymous reviewers for constructive comments on previous versions of this manuscript.

\section{REFERENCES}

Arak, A. 1983. Sexual selection by male-male competition in natterjack toad choruses. Nature 306: 241-242.

Ayres, C., and M. Dominguez-Costa. 2020. Heterospecific amplexus between Pelobates cultripes and Epidalea calamita in NorthWestern Spain. North-Western Journal of Zoology 16: 106-107.

Belanger, R. M., and L. D. Corkum. 2009. Review of Aquatic Sex Pheromones and Chemical Communication in Anurans. Journal of Herpetology 42: 84-191.

Carvajal-Castro, J. D., Y. Lopéz-Aguirre, A. M. Ospina-L., J. C. Santos, B. Rojas, and F. Vargas-Salinas. 2020. Much more than a clasp: evolutionary patterns of amplexus diversity in anurans. Biological Journal of the Linnean Society 129: 652-663.

Gherghel, I., A. Strugariu, D. Ghiurcă, and A.-S. CicortLucaciu. 2008. The herpetofauna from the Bistriţa river basin (Romania): geographical distribution. NorthWestern Journal of Zoology 4: 71-103.

Mačát, Z., and D. Jablonski. 2018. Pelobates fuscus (Laurenti, 1768) amplexing male (Linnaeus, 1758). Herpetozoa 30: 222-223.

Marco, A., and M. Lizana. 2002. The absence of species and sex recognition during mate search by male common toads, Bufo bufo. Ethology Ecology and Evolution 14: $1-8$.
Mollov, I. A., G. S. Popgeorgiev, B. Y. Naumov, N. D. Tzankov, and A. Y. Stoyanov. 2010. Cases of abnormal amplexus in anurans (Amphibia. Anura) from Bulgaria and Greece. Biharean Biologist 4: 121-125.

Moravec, J. 2019. Obojživelníci a plazi České republiky [Amphibians and Reptiles of the Czech Republic]. Praha: Academia. 464 pp.

Obert, H. J., and H. Schneider. 1978. Die Drüsen in der Haut der Rotbauchunke (Bombina bombina (L.); Discoglossidae, Anura): Art, Anzahl, Grösse und Verteilung unter natürlichen und experimentellen Bedingungen [The glands in the skin of the fire-bellied toad (Bombina bombina (L.); Discoglossidae, Anura): species, number, size and distribution under natural and experimental conditions]. Zeitschrift für microskopisch-anatomische Forschung 92: 241-272.

Pyron, A., and J. J. Wiens. 2011. A large-scale phylogeny of Amphibia including over 2800 species, and a revised classification of extant frogs, salamanders, and caecilians. Molecular Phylogenetics and Evolution 61: 543-583.

Schmidt, R. S. 1972. Release calling and inflating movements in anurans. Copeia 1972: 240-245.

Simović, A., N. Anderson, M. Anđelković, S. Gvozdenović, and S. Đorđević. 2014. Unusual amplexuses between anurans and caudates. Herpetology Notes 7: 25-29.

Speybroeck, J., W. Beukema, B. Bok, J. Van Der Voort, and I. Velikov. 2016. Field Guide to the Amphibians and Reptiles of Britain and Europe. London: Bloomsbury Wildlife. $432 \mathrm{pp}$.

Strugariu, A., and I. Gherghel. 2008. A preliminary report on the composition and distribution of the herpetofauna in the Lower Prut River Basin (Romania). North-Western Journal of Zoology 4: 49-69.

Toledo, L. F., I. A. Martins, D. P. Bruschi, M. A. Passos, C. Alexandre, and C. F. B. Haddad. 2015. The anuran calling repertoire in the light of social context. Acta Ethologica 18: 87-99.

Wells, K. D. 2007. The Ecology \& Behavior of Amphibians. Chicago: University of Chicago Press. 1400 pp.

Woodley, S. K. 2014. Chemical signalling in amphibians. In Neurobiology of Chemical Communication, Frontiers in Neuroscience Series, edited by MucignatCaretta, C., 251-280. Boca Raton: CRC Press/Taylor and Francis.

Zimić, A., A. Ćurić, A. Kolanek, M. Bonk, D. Herero, N. Peyer, C. Bühler, B. R. Schmidt, N. Martinez, K. Grossenabacher, and D. Jelić. 2018. Making too many mistakes: Cases of abnormal amplexi in European anurans. 2nd Balkan Herpetological Symposium, Poreč, Croatia. Poster. URL: https://www.researchgate.net/ publication/327822024_Making_too_many_mistakes_ Cases_of_abnormal_amplexi_in_European_anurans 